811.163.41-26"17/18"

811.163.41.08-1 Георгијевић Г.

https://doi.org/10.18485/sj.2021.26.1.2

\author{
АЛЕКСАНДАР М. МИЛАНОВИЪ ${ }^{*}$ \\ Универзитет у Београду \\ Филолошки факултет
}

Оригинални научни рад

Примљен: 10. 11. 2020.

Прихваћен: 12. 1. 2021.

\title{
СЛАВЕНИЗМИ У ДЕСЕТЕРАЧКИМ ПЕСМАМА ГЕРАСИМА ГЕОРГИЈЕВИЋА (1838)
}

У раду се анализира функција славенизама у епским песмама архијереја Герасима Георгијевића, испеваним у десетерцу и објављеним у делу Знаменитіи догађаи новіе србске исторіе (1838). Иако се у песмама опонаша фолклорни језик српских епских песама (десетерац, ијекавица, субјекат у облику вокатива), Георгијевић при опису устаничких дана и судбине студеничке обитељи у њима из тематских, стилских или метричких разлога активира и обиље славенизама, који неретко коегзистирају са истозначним облицима из народног језика.

Кључне речи: Герасим Георгијевић, славенизам, позајмљеница, турцизам, фонетски дублет, творбени дублет, синоним, конкуренција облика, коегзистенција облика, хибридност текста.

0. Како показују радови Исидоре Бјелаковић, Ирене Цветковић Теофиловић, Ане Мацановић и Милене Зорић, новија истраживања славеносрпских текстова све су усмеренија према лексици. Доводећи у фокус порекло, функцију или фреквенцију активираних речи у појединим текстовима или читавом опусу славеносрпских писаца, резултати ових истраживања сведоче и о генези, о смеровима настанка и развоја, али и о судбини хибридног идиома у служби књижевног језика. Два су разлога новој тенденцији у приступу славеносрпском језику: први је начелан и лежи у чињеници да је лексика у тумачењима дуго

*aleksandar.jus@gmail.com 
била запостављана на рачун графије, ортографије, фонетике и морфологије, па су млађи истраживачи уочили одређене празнине у постојећим сазнањима; други је конкретнији и везан је за податак да је у Матици српској обновљен рад на Речнику славеносрпског језика.

0.1. Сходно језичкој ситуацији у другој половини XVIII и у првим деценијама XIX в., у лексичким истраживањима посебну пажњу привлаче славенизми, а њихово проучавање има већ дугу традицију (уп. литературу у Стијовић 1992). Новија истраживања се у потрази за узроцима селекције лексике све више окрећу ка личности аутора: његовом образовању, лектири, службовању, путовањима, интелектуалним контактима и сл. Тако је и нама недавно пажњу привукао феномен који није детаљније анализиран: да се хибридна, славеносрпска лексика појављује и у делима образованих свештених лица, попут владике Петра Петровића Његоша (Милановић 2020). У њиховом опусу, наиме, појава славеносрбизама не може се тумачити као последица непознавања рускословенског, па ни српскословенског, језика. ${ }^{1}$

0.2. У новијим истраживањима славеносрпских текстова, такође, инсистира се на поставци да се анализе никако не смеју вршити без увида у стилску и жанровску норму текста, што је на трагу истраживања Никите И. Толстоја, а потом и Ане Кречмер (Милановић/Бјелаковић 2016). Метод упитника, развијан у истраживањима Александра Младеновића, највише методолошких слабости показао је управо зато што су у објављеним монографијама занемариване стилске и жанровске особености славеносрпских текстова.

1. Колико су личност аутора, жанр, тематика, метрика и стил епохе утицали на коначно лексичко уобличавање текстова из прве половине 19. века, покушаћемо да установимо анализом дела Знаменитіи догађаи новіе србске исторіе на кратко у везаном и простомъ слогу списани Герасімомъ Георгісвићемъ, епископом шабачкимъ, објављеног у Београду 1838. године.

1.1. Герасим Георгијевић је један од тројице српских архијереја хиротонисаних после стицања црквене аутономије и ,један од малобројних писмених људи у Србији тога доба" (Челиковић 2010: 263). Према сопственом сведочењу у књизи Знаменити догађаји новије српске историје, рођен је 1779. у Видину, на територији данашње Бугарске, а родитељи су му били влашког порекла. Георгијевићу, дакле, српски језик није био матерњи. Школу је учио у родном

\footnotetext{
${ }^{1}$ Вероватнија је претпоставка да се ту хибридна лексика појављује као последица утицаја лектире, односно као одраз стила епохе. Исто објашњење може се изнети и при утврђивању мотивације за напоредо активирање фонетских и творбених дублета: док се конкуренција или коегзистенција различитих облика у истом тексту код световних лица и може тумачити слабијим познавањем црквенословенске норме, чини нам се основаном претпоставка да је она у тексту школованог свештеног лица, добро упућеног у норму црквеног језика, по правилу стилистички, тематски или метрички мотивисана. Више о феномену конкуренције и коегзистенције облика у славеносрпској епохи в. Милановић 2014.
} 
месту, а потом се замонашио у Студеници. „Године 1799. митрополит рашко-призренски Јоаникије рукоположио га је за јерођакона, а следеће године за јеромонаха" (Челиковић 2010: 264). Пред турском одмаздом, заједно с другим монасима напушта Студеницу 1806. године и стиже у манастир Враћевштица $^{2}$, где остаје до пропасти Првог српског устанка. У манастиру се упознао и спријатељио с Милошем Обреновићем. Године 1813. стиже у манастир Фенек, потом у Гргетег и Вољавчу. Укључује се у припреме новог устанка, у којем потом активно учествује. Године 1831. хиротонисан је за епископа и постављен за епископа шабачког. У манастиру Каленић остао је до 1839, када се враћа у Студеницу. Умро је 29. марта 1839.

1.2. Георгијевићево дело лингвистичку пажњу привлачи различитим аспектима, али пре свега једним кључним, а то је стилска и жанровска хетерогеност текста. Наиме, као што и наслов каже, Знаменити догађаји новије српске историје писани су и у стиху (у везаном слогу), у првом делу, али и као историјска хроника - сведочење очевица и актера, а потом и као мемоари, све у простом слогу у другом делу књиге. Уз наведено, ваља истаћи и да је у питању једна од првих књига објављених у Србији кнеза Милоша Обреновића, да је штампана у Књажеско-српској књигопечатњи славеносрпском графијом и ортографијом (укључујући морфонолошки и историјски проседе), али и да се у Георгијевићевој ћирилици већ појављују вуковске графеме $<\hbar>,<\hbar>$ и $<џ>{ }^{3}$ Цензор књиге био је Димитрије Исаиловић.

1.3. Иако је о Георгијевићевој књизи без лингвистичке анализе изнет суд да је писана „углавном на веома чистом народном језику” (Витезовић 2010: 254), таква оцена се, уз извесне ограде, може изнети само за њен први део. Наиме, троделна структура књиге условљава и хетерогени језик и стил у књизи: у првом делу узор је народна епска десетерачка поезија писана српским фолклорним језиком (са народним језиком у својој основи), ${ }^{4}$ а у другоме узор су дела прво историографског, а потом мемоарског садржаја, писана рускословенским, руским и славеносрпским језиком. Георгијевић се несумњиво језички

${ }^{2}$ Савремени топоним (и име манастира) је Враћевшница.

${ }^{3}$ Графема $<$ џ $>$ појављује се за фонему /dž/ у двама примерима истог турцизма: џебана (11), џебане (28). По правилима морфонолошког правописа, међутим, Георгијевић пише <ч> у: Отачбини (14), наручбину (71). Наведени графематски систем био је у складу са Милошевом Уредбом о цеензури (1832), којом је изричито забрањено штампање књига у којима има „писмена љ, њ и ј по ортографији познатога списатеља Вука Стефановића Караџића, или које су написане без малог и великог јера и без јери". Употпуњавање славеносрпске ћирилице управо графемама $<$ ћ, ђ, џ> регистровао је и Павле Ивић (1998: 195-196).

${ }^{4}$ Витезовић (2010: 255) прави паралелу са песмама Филипа Вишњића, али и са Србијанком Симе Милутиновића Сарајлије. Потенцијални Сарајлијин утицај на Георгијевићев језик и стил тек би требало подробно испитати. Познато је да је Сарајлија у Србијанции, у модификованом епском десетерцу, активирао велики број лексичких и граматичких славенизама (Иванић 1993: XXI, XXVI, XLII, XLII-XLVI). 
неретко поводио за лектиром. Наша анализа треба да покаже како се таква структура Георгијевићевог дела одразила на изабрану лексику и лексичке односе, али ће због ограничености простора на овоме месту бити обрађен само први, песнички део књиге.

2. Шест епских песама у десетерцу је, дакле, по узору на народну поезију спевао православни свештеник којем српски језик није био матерњи и који га је учио у манастиру Студеница, што је сасвим атипична ситуација. Опонашање фолклорног језика народне поезије наглашено је ијекавским облицима у Георгијевићевим стиховима: Одъ Видина до бієла Скадра 3, На далеко може се виђети 6, Онъ є прађедъ и отацъ свимъ нама $8,{ }^{5}$ И желіо очима виђети 12 , Желили су очима виђети 15 , Іошть пріє се беше преставіо 24 , Светогъ Краля кадъ су понієли 26, У манастиръ Фенекъ однієли 36, Светогъ Краля да би пренієли 71. Актуелизацију тона народне поезије Георгијевић је на једном месту постигао и граматичким субјектом у форми вокатива: Тако с' люто Царе разгнъвіо 35.

С друге стране, аутентичност „чистог” народног језика, у вуковском поимању тог појма, лако је оспорити једноставном анализом фонетских црта Георгијевићевих речи. Наиме, у лексемама из народног језика лако се уочава немотивисана фонетска коегзистенција облика, карактеристична за славеносрпске текстове. Тако се наспрам само једног облика са групом $/ \mathrm{mn} / \mathrm{y}$ прилогу много (Много су се они потрудили 5) јавља скоро 40 различитих облика са дисимилацијом, групом $/ \mathrm{ml} /$, у истој основи (Млогогъ яда да се нажалуємъ 3, за млого се то време водило 6, Гди су мъста млога и преславна 8 , Наши су се млого световали 8, Млого робль са собомъ одвели 9, Димъ и ватру премлогу просули 11 итд.). Облику наија, са изгубљеним /h/, конкурише облик нахија (Наію 5 Наіям' 42, Наіє 43 : Нахіи 5, 13, 30, Нахію 18, 30, Нахіє 34, Нахіям’ 35 итд.), а облику дуовник (Дуовниче 57) облик духовник (Духовницы 56). Међу фонетским дублетима су и облици гди и где (Гди $8:$ Гдъ 8 ), и сл. ${ }^{6}$

За даљу анализу веома је важно истаћи да Георгијевић није желео да код читалаца створи илузију народног певача који пева уз гусле, већ је на трима местима експлицитно истакао како је он своје песме написао, да би их оставио млађим генерацијама: То не велю, да кога оскорбимъ, / Већь на срцу горко ядикуємъ. / То є онда было па и прошло, / А садъ ми є текъ на руку дошло, / Да имъ ово укратко напишемъ, И на знань млађима оставимъ (стр. 14); Твоє яде я садъ грђшный пишемъ, / И плачући прегорко уздишемъ (33); Сада ово писат'

\footnotetext{
${ }^{5}$ УП. напоредни облик: И одъ стары светы Прадьдова 73.

${ }^{6}$ У тексту се запажа и типична ортографска конкуренција облика у славеносрпским текстовима: нпр., $<$ ы $>:<$ и> у позајмљеницама (манастыръ 21, Манастыръ 23 : Манастиръ 24, манастиръ 36,47 ) или <-ь > : <-ъ> иза именица са финалним /ć/ (у Калинићь 41, 60, 71 : у Калинићъ 72).
} 
предузимамъ, / ЛЂпу повъсть имамъ да искажемъ (41). ${ }^{7}$ Оваква аутопоетичка позиција, самоодређење писца а не певача (казивача), условила је и карактеристичну селекцију лексичких и морфосинтаксичких средстава у песмама будући да је писани језик намењен будућим генерацијама нужно подразумевао и виши стил оличен у књижевном језику. Такође, одређење писца као грешног, при томе, недвосмислено упућује и на поетичко угледање на средњовековне текстове и језичко-стилски репертоар њихових дијака.

3. За разлику од народних песама које због своје природе наслове нису ни имале, Георгијевићеве епске песме имају наслове који су језичко-стилски сасвим у славеносрпском духу: „Сказаніє о паденію и разоренію свете обители Студенице” (3), „Второ сказаніє о падежу Србске Шумадіє, и о преселенію светога Краля Студеничког у Цесарію” (26), „Плачъ ондашный Сербіє” (33), „Повьсть о нововозвышенію Шумадіє, о производенію Милоша Обреновића за Княза и Господара Сербіє: и о повратку мощій светога Краля Студеничкогъ изъ Цесаріє у Калинићь” (41), „Плачъ о погинувшима на Чачку” (54) и „Радость Сербіи" (73)9. Најлепша илустрација разлике између језика и стила наслова и самих песама налази се у другој песми, која после наслова „Второ сказаніє о падежу Србске Шумадіє, и о преселенію Светога Краля Студеничког у Цесарію” започиње стиховима: „Повъсть другу сада започинђмъ / О страданю и о бъгству нашемъ" (26). Наспрам синтагме из наслова второ сказаније, која је репрезент високог стила, стоји синтагма повест друга, у којој уочавамо благо стилско спуштање ка језику устаника, а исти однос запажамо између изведенице са цсл. суфиксом -ије у наслову (преселеније/пресељеније) и оне са народним суфиксом -ње у другом стиху (страдање).

Већ је давање типичних славеносрпских наслова епским десетерачким песмама морало утицати на хибридност језика у читавоме првом делу књиге. Ипак, у првој половини XIX в. наслов морамо посматрати и као стилски изолован сегмент у односу на сами текст. Познато је, наиме, да су наслови, као најистакнутија места текста, неретко били неупоредиво више лексички и синтаксички славенизовани у односу на остатак текста. То у Георгијевићевој књизи још у много већој мери важи и за пропратне текстове на крају песама, који заправо представљају типичне екскурсе. Њихова је функција да као документ о месту и времену настанка песме обезбеде утисак максималне аутентичности песничког казивања, а исписани су по узусима записа из средњовековне књижевности: „Грђшный Іеромонахъ Герасимъ Студеничанинъ, списа ову повъсть, у 1813-ой години 5-гъ Юнія у Монастиру Враћевщицы” (25); „Грьшный Іеро-

${ }^{7}$ Само на једном месту ствара се привид усменог казивањ $а$, односно певањ $а$ : Оно време беше, па и прође, / Алъ садъ чуймо, шта насъ друго снађе (17).

${ }^{8}$ Цитатна веза са насловима чувених песама Захарија Орфелина јасно је наглашена.

${ }^{9}$ И овде је интертекстуална веза са Орфелиновим песмама несумњива, иако базирана на контрасту у односу на Орфелинов наслов. 
монахъ Герасимъ Студеничанинъ списа ове стіхове у Манастиру Волячи 1814 године, Юлія 6гъ” (40); „У Рудничкой планини, Манастыру Благовьщенія, у години 1828-ой Януарія 22-гъ. Герасимъ Студеничанинъ” (74). Пропратни текст уз четврту песму имао је функцију информације о структури књиге: „Конацъ првоме походу” (53), а дужи подножни екскурс „Льта Хрістова 1814” (54-63) који прати песму „Плачъ о погинувшима на Чачку”, у прозној форми даје допуне песничком опису историјских догађаја.

4. Стога је за потврду хипотезе о хибридности језика Георгијевићевих песама неопходна и лексичка анализа самих стихова, а њоме издвајамо обиље славенизама сасвим некарактеристичних за језик српских народних епских песама. Оваквој Георгијевићевој селекцији лексике пресудно доприноси, поред свештеничког чина аутора, и тематика песама: у првим трима песмама опева се судбина студеничке обитељи, која напуштајући манастир носи мошти Стефана Првовенчаног, а потом дели судбину народа у устаничким данима испуњеним селидбама и неизвесношћу, да би се напослетку вратила у Србију. Славенизми тако постају и средство актуелизације исказа, као у примеру разговора калуђера с митрополитом: „Велимо му, да смо на путъ пошли, / Да съ народомъ идемо у Турску, Да с’ вратимо своме Отечеству. / „Па смо дошли, полюбит’ Вамъ руку / „По закону нашемъ црковному, / „И благословъ одъ Васъ да пріимимо, / „Благодарность топлу Вамъ воздамо, / „За заштиту, кою сте намъдали, / „А съ тимъ любовь Богу указали” (39). И исказ архимандрита Мелентија Никшића, на пример, верно је лексички дочаран: „Оніи люди мени су познани, / „Кано честни и врло любовни (22).

Неретко је у овим песмама опис догађаја с религиозним садржајем условио високу фреквенцију славенизама у стиховима: И ньму се сердечно молили. / Сила наша слабачка є была, / У мало се села состояла (6); Светогь древа и честнога креста (21); Кресть о ньойзи честный, животворный (21); У цркву га честно положили. / Све вообще насъ су дочекали, / Велику намъ любовь указали (23); Іоштъ држаше церкве правленіє (31).

Четврта песма пак описује устанак под Милошем Обреновићем, тематика се мења, а с њом делимично и стил јер фреквенција славенизама опада, али они и даље остају значајне стилеме, што важи и за преостале две песме: пете, дуже, исписане у плачевном тону због погибије устаника, и шесте, краће и завршне, у радосном тону због васкрснућа Србије. Тако се на пример славенизмима описују и поступци Милошеви и устанички: Лњпе имъ је совъте давао (44), Зато га є Милошъ возлюбіо (47), Юначествомъ шанацъ су разбили (44). Док је трећи славенизам метрички условљен, у прва два видимо само подизање стила при опису поступака славне и песнику омиљене личности.

5. Сасвим у складу са карактеристичним цртама славеносрпског језика, оптерећеног бројним дублетима и укрштањима облика из српскословенског 
и рускословенског језика са народним облицима, и језик Георгијевићевих песама показује истовремено ослањање на различите изворе одабраних лексема. Коегзистенције облика су бројне и разноврсне, узроци напоредности су различити, а само неке од облика можемо мотивисати метричким разлозима.

Поједини славенизми имају искључиво српскословенски фонетизам, одомаћен и у народном језику, као на пример лексема свештеник (Свештеникомъ 25, Свештеника 36, Свештенике 36 , Свештеникъ 68, Свештеницы 68 , 71). Наспрам овог примера, међутим, стоје они са доследним рускословенским фонетизмом, попут лексеме отечество (За слободу и за отечество 15, У своє се вратит' Отечество 38, Па да живе у свомъ Отечеству 70). И многе лексеме које су само једном активиране у тексту имају само руски/рускословенски фонетизам, попут лексема Болгарија и Греција: По Сербіи и по Болгаріи, / По Греціи и по Влашкой Земльи (4). Већ само укрштање облика из двеју редакција типична је карактеристика славеносрпског текста, коју је Георгијевић пренео у своје песме актвирајући бројне славенизме, од фонетских до лексичких. Они у тексту неретко коегзистирају са народним облицима.

6. Тако у песмама бројношћу и фреквенцијом доминирају народне речи са вокалним /r/: држао 11, држали 15, смртну 15, задржати 16, кршу 22, брже $27,42,45$, тврђу 28, држале 34, држи 37 , врло 43, свршисмо 47, тврдо 48, мртавъ 48 , прекрстимсе 56 , грли 62 , мртва 63 , загрли 63 , свршили 70 , потврдили 70 , трговцы 71 итд. $^{10}$ Две речи потврђене су, међутим, само са графематском секвенцом <ер>, иза које је могао стајати, судећи према Георгијевићевом ортографском систему, и идентичан руски тј. рускословенски фонетизам: четвертой години (4), у Гергетегъ (38). ${ }^{11}$

6.1. Већу пажњу привлаче примери коегзистенције облика истих лексема, као код графематске и фонетске напоредности $<\mathrm{p}>$ : $\langle\mathrm{ep}>$ : $<$ 'p $>$, за коју је немогуће пружити метричко објашњење. Овде имамо три групе примера са истим односима: а) ирква : иерква (цркве 5,22 , цркви 7, 68, цркву 18,36 , 68 : Церквомъ 18, церкву 39, Церкви 71 : Ц’ркву 56); б) црковни : иерковни (И црковну сву славу чинили 7, У црковнимъ кньигама ће найти 17, Управ’ пође на црковна врата 19, И црковна врата извалише 19, Свемъ црковнымъ тада управляше 35 : И понеше утвари церковне 18 , Да церковнымъ онъ дъломъ управля 72 : Све ц’рковне ствари избавіо 32); в) први : перви (првый градъ 4 : первимъ дворовима 4, первогъ времена 22, первіи Кметови 68 : п’рвый владаше 5). ${ }^{12}$

${ }^{10} \mathrm{y}$ једном примеру потврђено је и вокално /r/ испред вокала, а слоготворност Георгијевић бележи апострофом: вр'овный 31.

${ }^{11}$ Сасвим је могуће, такође, да је у питању био и само механички пренет ортографски манир.

${ }^{12}$ Пример са апострофом на месту <е> вероватно посредно сведочи да је Георгијевић у свом језичком осећању, формираном у манастиру, имао и облике ca /er/ на месту народног вокалног /r/: Да сва Босна на Сербію г’рне 28. 
6.2. Примери лексема са кореном срб- показују занимљиву правилност у Георгијевићевим песмама. Са секвенцом <ер>, то јест са групом /er/, доследно се појављује само лексема Сербија, док се све остале лексеме појављују искључиво са народним фонетизмом, дакле са графемом $<\mathrm{p}>$, односно вокалним $/ \mathrm{r} /$ : а) Сербија: Сербіи 3, 4, 6, 7, 73 х 2, Сербія 26, 31, Сербію 28, 39, Сербіє 72, 73, Сербіо 73; б) српски: Србскіи Патріярси 7, Коренъ Србскій 8, Србска войска 8, Србско царство 15, Господару Србскомъ 23, Србске кћери 33, 74, Србске жице 72, Србскимъ [...] Княземъ 73, Србски Царева 73; в) Србљи: Србльи 14, Србль 14, 65, Србльмъ 29; г) српство: Србство 67.13

7. Поједини активирани славенизми само су фонетски маркирани у односу на лексеме које су биле уобичајене у народном језику: христјанство (Свем' Хрістянству была і' она славна 4), љуубов (Брачну любовь вьнчанלмъ свезали 17, Стару любовь съ ньиме іошть држасмо 21, Братску любовь ньима указао 71), љубовно (Тако смо се любовно сложили 25, Да намъ Богъ да, любовно живити 25, Любовно имъ спомоществоваше 71, Да намъ Богъ да, любовно живити 74), испольавати (Оће въчно да се исполнява 34), казан (Казнь нашу я виђо очима 34), чест (Какова се честь Везиру дає 69, Велику су честь имъ учинили 71), честан (Честну руку онде цвливасмо 39), чесно (Свете мощи честно дочекао 36, И у цркву честно положили 36 , После пашу честно приватіо 66, Те є честно Пашу оправіо 67, Честно су іи тамо дочекали 69), књаз (Тако Милошъ Србскимъ поста Княземъ 73, Србскимъ Княземъ намъ именованна 73). ${ }^{14}$ Како се број слогова у овим речима поклапа са народним облицима, очито је да наведени славенизми немају метричку већ само стилску и тематску условљеност. Степен фонетске адаптације црквенословенске лексике различит je, па се, на пример, поред облика всемогућ (Благій Хрісте, всемогућій Боже 10) појављује и облик свеопшти (О ондашньой свеобщей пропасти 14$).{ }^{15}$

8. Посведочене су именичке и придевске изведенице с фреквентним рус./ рсл. суфиксима: -ество (Юначествомъ шанацъ су разбили 44, Юначествомъ силнымъ навалише 66), -ески (Већь пођоше сви на бой дружески 12, Дружески су върно се држали 15, Посьдисмо дружески на миру 24), -елни (Иза овогъ погибелногъ рата 16). Исто важи и за префиксе (и предлоге) са идентичним фонетским карактеристикама: в- (Въ Шумадіи манастыръ быяше 21, Аманети коим' су вручени 31 , И братински взаймно поздравили 46), во- (Пакъ по реду све насъ вопрошава 37, Сви вообще онде с' намъстили 72, Сви вообще,

${ }^{13}$ Усамљени изузетак од наведеног система представља пример: Збогъ Сербскіє изгибши юнака 33.

${ }^{14}$ Овде би ишао и пример са предлогом у цсл. форми /ot-/: Оттуда се къ нама повратіо 67, Започеше с' оттуда являти 70 .

15 Занимљиво је да су идентични фонетски ликови ових речи забележени и у Његошевом језику (Стијовић 1992). 
велико и мало 74, Воля твоя буд’ вовъки съ нама 74) и воз- (Капетанъ $є$ Ђуру возлюбіо 9, Зато га $є$ Милошъ возлюбіо 47, Споменисе, воздай Богу хвалу 73).

Поред изведеница са неким фонетски обележеним суфиксом, појављују се и оне са заједничким, црквенословенским обликом ове творбене морфеме, попут суфикса -ство (Дьдинство 15 , подданству 15 , людства 23 , робства 34 , Старешинство 42, Србство 67), -ост: Сладость 25, 26, храбрость 47, хитрость 64 , сигурность 65, Милость 71) или -тељ (Настоятель 25, 37; поспьшествователь 25, Хранитель 36, Властитель 37). Изведеница с цсл. суфиксом -ије има шест: житије (За ньгово житіє преславно 8, У житію Божьгь Алексія 16), сраженије (Велико ће сраженіє быи 12), извјестије (Изъ Тополе съ извъстіємъ дође 20), правленије (Іоштъ држаше церкве правленіє 31, Манастирско држи правленіє 37), желаније (Изяви му своє желаніє 37), условије (Условія мира потврдили 70). ${ }^{16}$

9. Бројни лексички славенизми доказују да над метричком условљеношћу њиховог активирања доминира тематска: погибел (Ал' гди і' одпоръ таквой погибели 17), муж (Беше Іосифъ, мужъ отмъногъ дара 23, Іоштъ $є$ къ себи мужеве призвао 72, Благогъ мужа праве Србске жице 72), надежда (У той народъ надежди быяше 42), ијел (Напредую къ предузетой цъли 72), (пре) скорбан (Тужећ' скорбне премъне казуємъ 8, те оданде скорбни се кренемо 21, Я чуюћи те прескорбне гласе 56, Пакъ прескорбанъ и оданде пођемъ 60), скорбно (И прескорбно животъ окончао 13, Исказати врло б' скорбно било 49), (о)скорбити (То не велю, да кога оскорбимъ 14, Споменисе, немой скорбити 73), божествени (И ньгова божественна воля 72), прочи (А прочіи смо на Чачку стаяли 44, „Кадъ на Чачку остаде ти глава!” и проч. 53), чрезвичајни (Чрезвычайну храбрость удвоіо 64), сердечно (У свомъ дому сердечно насъ пріими 22 ), конечно (Милошъ и самъ конечно дознає 69), печално (Печално $є$ погледати бы 15), полезно (Сръ є свьту сходно и полезно 17), зовом (Баряктара Кара-Ђорђевога, / Танасія Раићъ зовомога 8, Изиђоше горе на высину, / ђаковачку зовому планину 18), кром(j)e (Кромъ єдногь свемогућегъ Бога 42) и сл.

Узвишености Георгијевићевог стила доприносе и калкиране сложенице са првим елементом добро- и благо-: добротворни (Милостивъ намъ бы и добротворанъ 36), благодарност (Благодарность Богу учинише 45), благородни (Показуюћ' срце благородно 69).

${ }^{16}$ Глаголских именица са народним суфиксима -је и -ње незнатно је више, седам: поуздање (И представля слабо поузданъ 18), живљење (О живльню нашемъ споменули 24), страдање (О страданю и бъгству нашемъ 26), бежање (При бъжаню штоно се превезе 35, У бъжаню бъдни пострадати 50), певање (Да б’ гди чуо птичієгъ пьваня 60), путовање (Я му сказа моє путовань $61)$, јадиковање (И виђено свуд’ ядикованъ 61) и ратовање (Ратованя въштину развіо 64). 
10. Обиље славенизама у Георгијевићевим песмама условило је и више примера коегзистенције руског/русколовенског и народног облика појединих лексема. Узроци напоредне појаве облика различити су.

10.1. У првој групи од три пара примера налазе се коегзистирајуће форме које се не могу тумачити метричким разлозима будући да им је број слогова исти: а) монастир : манастир (Монастири разорени быше 33 : Я самь слуга Манастира славна 3, И већь близу къ Манастиру дошли 18, Въ Шумадіи манастыръ быяше 21, Тадъ Игуменъ истогъ Манастира 23, Од’ как' онде сви у Манастиру 24, Враћевщица манастирь му беше 47 итд.). ${ }^{17}$ б) срдие : срие (Тадъ іоштъ выше у срдцу ти с' мили 7 : Горко тужим, и у срцу трунемъ 8, Будите ми срца юначкога 10, Већь на срцу горко ядикуємъ 14, Бъдномъ старцу срце се смутило 19, Срце бы се у нъму топило 19 итд.) ${ }^{18}$ в) игумен : игуман (Мартиріє Игуменъ намъ беше 18, Тадъ Игуменъ истогъ Манастира 23 : Игуманъ $є$ теб' овамо посл’о 12, Єръ Игуманъ Іосифъ кой є быо 24).

10.2. У другој групи коју чине три пара примера налазе се коегзистирајуће форме које се морају тумачити метричким разлозима будући да им број слогова није исти, док им је контекст сродан, а значење лексема готово исто: a) јуначество : јунаштво (Юначествомъ шанацъ су разбили 44, Юначествомъ силнымъ навалише 66 : И погибе за своє юнашство 49, И юначство опетъ придобила 64); б) совјетовати : световати (Што є боль совътоват' знао 9, Но што више я ю совътуємъ 58 : Наши су се млого световали 8 , К’о сродницы братски световали 12); ${ }^{19}$ в) совершити : свршити (Савъ већь говоръ кадъ су совершили 24 : Свету тайну у ньима свршую $21,{ }^{20}$ Тако Турцы договорь свршише 50). У свим наведеним примерима круте законитости метрике погодовале су коегзистенцији славенизама и истозначне народне лексике. Наведеним примерима, додајмо, сасвим је сличан и пример коегзистенције две тада живе народне форме хидронима Дунав : Дунаво, овде условљене метричким разлозима: Те навыше узъ Дунавъ пођоше (29), Къ Неготину узъ Дунавъ навыше (30) : Како ћ’ даль узъ Дунаво поћи (29).

10.3. Од наведених примера суштински се разликује пар сохранити : саранити, у којем је дошло до семантичке диференцијације, те први облик с рускословенским фонетизмом има значење 'сачувати, похранити', док други

${ }^{17}$ Народна форма са метатезом * намастир не појављује се у тексту. Облика манастир у песмама је укупно 11, а монастир два, рачунајући и одредбу уз песму: У Монастиру Враћевщици (25).

${ }^{18}$ Према само једном хибридном примеру стоји двадесетак примера са народним фонетизмом. УП. и деминутив: на срдашцу 9 . Нема форме * сердие.

${ }^{19}$ Одговарајућа именица се појављује само једанпут, у рсл. форми совјет (Льпе имъ $\epsilon$ совђте давао 44).

${ }^{20}$ Иако је тематика у овом примеру налагала рускословенску форму, метрички разлози пресудили су у корист народне форме. 
с народним фонетизмом има данашње значење (Свете ствари гди бы сохранили 21, И древности Србске сохранили 24, Светогь Краля да би пренієли / И остало што су сохранили 71 : Погинувше тражит' отидоше. / Свакій свога овде саранисмо 50).

11. Попут коегзистирајућих фонетских дублета, у Георгијевићевим песмама појављују се напоредо и творбени дублети и лексички синоними, стварајући понекад занимљиве семантичке низове: а) отечество : отацбина : домовина (За слободу и за отечество 15, У своє се вратит' Отечество 38 , Па да живе у свомъ Отечеству 70 : Отачбини върно послужіо 14 : Къ домовини милой поитила 61); ${ }^{21}$ б) дружба : дружина : друштво (И по томе дружби говораше 10, Съ дружбомъ брзо разговоръ поведе 45 : Браћо моя, и върна дружино 10, Одъ дружине да се раздвоимо 38, Затекосмо сву нашу дружину 18 : Дружство наше жельно чекаюћи 19, Већь устасмо да се дружство креће 20 , Съ ньимъ у дружству свудъ се налазіо 72); в) бегство : бежање (О страданю и бъгству нашемъ 26 : При бъжаню штоно се превезе 35, У бъжаню бъдни пострадати 50). Судећи према броју слогова у наведеним примерима, јасно је да су при избору понегде превагнули метрички, а понегде тематски и стилски разлози.

12. Некарактеристичне за фолклорни језик, али сасвим типичне за славеносрпски, па и актуелни народни језик у време устанка, јесу поједине лексичке позајмљенище које је Георгијевић активирао: командант (Кара-Ђорђу главни Комманданти 27, И Коммандантъ Кара-Ђорђу знатный 28, Комманданти свудъ іи наредише 28, Съ ньимъ нБгови Комманданти главніи 32); контумаи (Контумацу време да изиђе 36); плотон (Топомъ бію, сипаю плотоне 48), фамилија (Фамиліє Раића Танаска 56, Фамиліє Шарге Өеодора 59, Фамиліє Попа Милована 60, Съ Фамиліомъ онде с' намъстіо 72), пардон (Одъ Милоша пардона искати 65), депутираи (Депутирце у Стамболь пратіо 70), ходатај (Мелентіс ходатай имъ беше 71).

13. Мада је у поменутој литератури утврђено да је у Георгијевићевој књизи „зачуђујуће мало турцизама” (Витезовић 2010: 254), они су у песмама заправо бројни, нарочито у опису битака, али и стања у тадашњем друштву. Бројношћу, фреквенцијом и значењем дочаравали су овде тон народне песме, али су, додајмо, турцизми сасвим уобичајени били и у славеносрпским текстовима: барјактар (Баряктара 5), ћаба (ћаба 7), шер (ше’ру Новога Пазара 8), барјак (Барякъ 11, баряке 18), караула /караули 20), кумбара (кумбара 28), ордија (ордіи 29, ордію 69), везир (Везиръ 29, 35, 43, 65, 67, 68, 69, 70, Везиру 67, 68, 69, Везира 68, Везиромъ 70), ћуприја (ћупріє 29), хатлија (Хатліє 30), запт (запть 34), ферман (Ферманомъ 35, 70), мур-сајбија (Муръ-Сайбія 35),

${ }^{21}$ Већ је речено да Георгијевић наспрам рускословенског облика отечество није активирао ниједан од двају тадашњих конкурената, тј. фонетских варијанти: *отачаство из српскословенског и *отачество из славеносрпског језика. 
зулумћар (Зулумћаре 35), муселим (Муселиме 35), адет (адетъ 39, адету 56, 69), вилајет (вилаєть 40), зулум (зулумъ 41, 69, зулума 41, 69, 70, зулумомъ 42), силај (силай 41), токе (токе 41), касаба (по касабам' 42, У касабам' 43, На касабу 43), топ (топа 47, 65, топови 48, топове 48, 49, Топомъ 48, 65), алај (На Алає 48), јуриш (юришъ 48, 66, юришемъ 48, Юришомъ 48), куршум (куршумъ 48), табор (таборь 49), абар (Одма абаръ свой войсци дадоше 50), сексана (И товарне конъ и сексане 50), конак (конаку 51, конакъ 52), була (Була’ 51), nама (Пашу 53, 66, Паша 66, 67, Паши 66), бабо (бабо 58), земан (земана $59)$, кувет (Већь и куветь свой су изгубили 65), чалма (чалму 66), хат (хата 67), nусат (Паша иште пусатъ да се даде 67), раја (раая 67), кабулити (Онъ кабули 67), делија (Делія 68), султан (Султана 69), забит (Забита 69), изун (Те съ изуномъ изъ Немачке пођу 71) итд. Посебно је занимљив Георгијевићев поступак навођења контактних синонима (турцизам - народна реч), чест почетком 19. века у делима писаним административним, публицистичким и научним стилом (Милановић 2013), али редак у књижевним делима: Онда найпре абери (гласови) дођоше: / Одъ Видина Турцы ударише (28). Јасно је да домаћи синоним наведен у загради ремети метричку правилност, те он, заправо истовремено и јесте и није интегрални део песме.

14. Песме епископа Герасима Георгијевића сведоче о песничком језику свештеника у народном устанку, насталог на основици фолклорног језика и измешаног са живим говором устаника. Преузимајући актуелну устаничку лексику (командант, контумаи, плотон, депутираи, ходатај), користећи одомаћене турцизме из народне поезије, али и ослањајући се значајно на црквенословенизме и друге славенизме из тематских, стилских и метричких разлога, аутор наступа као писац, а не као народни певач, и тражи виши стил свога епског певања којим као епископ описује аутентичне догађаје. Будући да Георгијевић пише о судбини манастирске обитељи у народном устанку, хибридном би се могла оквалификовати и тематика песама. Хибридности текста доприносе и наслови песама, написани у славеносрпском духу, у којима број славенизама расте, као и пропратне напомене на крају песама којима се оне локализују. И славенизми који коегзистирају са другим славенизмима или народним речима у песмама условљени су тематски, стилски и метрички. Нигде где је број слогова у славенизму исти у односу на народну реч или други славенизам не може се говорити о метричкој условљености, већ се мотивација препознаје на стилској или тематској равни.

И анализа Георгијевићевих песама, као и шири увид у штампану продукцију током 30-их година XIX века, све нас више утврђују у мишљењу да је првобитна, стилски неусловљена језичка несигурност славеносрпских аутора из орфелиновске епохе временом прерастала у стилски манир аутора из доситејевске епохе. Другим речима, изнуђена конкуренција облика из орфелиновске епохе прерастала је с временом у свесну коегзистенцију облика као стилску 
категорију доситејевске форме славеносрпског језика, где се очито посебно ценила као варијација која спречава монотоност у тексту. Из текстова писаних доситејевским славеносрпским језиком ова стилска карактеристика преносила се и на поједине текстове писане народним језиком у првој половини XIX века.

\section{ИЗВОР}

Знаменитіи догађаи новіе србске исторіе на кратко у везаном и простомъ слогу списани Герасімомъ Георгієвићемъ, епископом шабачкимъ, У Бъограду, Печатано при Княжеско-Србской Кньигопечатньи, 1838 .

\section{ЛИТЕРАТУРА}

Витезовић 2010: Милован Витезовић, Писац епског сећања Герасим Георгијевић, у: Знаменитіи догађаи новіе србске исторіе на кратко у везаном и простомъ слогу списани Герасімомъ Георгієвићемъ, епископом шабачкимъ (прир. Борислав Челиковић), Београд: Службени гласник, 253-262.

Иванић 1993: Душан Иванић, Пјеснички споменик српских устаника, предговор у: Симо Милутиновић Сарајлија, Сербијанка, Београд: Српска књижевна задруга, VII-LXXII.

Ивић 1998: Павле Ивић, Преглед историје српског језика, Сремски Карловци - Нови Сад: Издавачка књижарница Зорана Стојановића.

Милановић 2013: Александар Милановић, Језик весма полезан, Београд: Друштво за српски језик и књижевност Србије.

Милановић 2014: Александар Милановић, Језик Јована Суботића, Београд: Чигоја штампа - Филолошки факултет.

Милановић 2020: Александар Милановић, Његош и славеносрпска традиција, у: Његошев зборник Матище српске (ур. Миро Вуксановић, Јасмина Грковић-Мејџор и Мато Пижурица), 4, Нови Сад: Матица српска, 91-102.

Милановић/Бјелаковић: Александар Милановић, Исидора Бјелаковић, Толстојева периодизација и питање жанра, у: Slavische Geisteskultur: Ethnolinguistische und philologische Forschungen. Teil 2 / Славянския духовная культура: этнолингвистические и филологические исследования. Часть 2 (ред. А. А. Алексеев, Н. П. Антропов, А. 
Г. Кречмер, Ф. Б. Поляков, С. М. Толстой), Frankfurt am Main Bern - Bruxelles - New York - Oxford - Warszawa - Wien: Peter Lang, 2016, 197-217.

Средојевић 2004: Александар Средојевић, Герасим Ђорђевић, епископ шабачки (1831-1839), и његово доба, Београд: Богословски факултет СПЦ.

Стијовић 1992: Светозар Стијовић, Славенизми у Његошевим песничким делима, Сремски Карловци - Нови Сад: Издавачка књижарница Зорана Стојановића.

Челиковић 2010: Борисав Челиковић, Герасим Георгијевић (1779-1839), у: Знаменитіи догађаи новіе србске исторіе на кратко у везаном и простомъ слогу списани Герасімомъ Георгієвићем, епископом шабачкимъ (прир. Борислав Челиковић), Београд: Службени гласник, 263-267.

\section{SLAVIC LEXICAL BORROWINGS IN PENTAMETRIC POETRY BY GERASIM GEORGIJEVIĆ (1838)}

\section{Summary}

The paper studies the role of Slavic borrowrings in epic poetry authored by Serbian archiepiscope Gerasim Georgijević. The poems, which are all in pentameter, were published in Знаменитіи догађаи новіе србске исторіе на кратко у везаном и простомъ слогу списани Герасімомъ Георгієвићемъ, епископом шабачкимъ, in Belgrade in 1838. Although Georgijević tended to imitate the folk language of Serbian epic poetry such as the pentametric verse, iekavian dialect and subject in the vocative, he also used many Slavic borrowings when describing the days of the uprisal and the fates of the monks from Studenica monastery. Such Slavic borrowings often co-exist with the synonimous words from the folk language and the reasons for their usage in Georgijević's poetry are of stylistic, thematic and metrical nature.

Key words: Gerasim Georgijević, Slavic lexical borrowing, lexical borrowing, Turkish lexical borrowing, phonetic doublet, formation doublet, synonim, competition of forms, form co-existance, text hybridity. 